\title{
IHДOIPAHCbKI МOBИ
}

УДК 81

DOI https://doi.org/10.32838/2710-4656/2021.4-1/49

Кшановський О. О.

Інститут мовознавства імені О. О. Потебні Національної академії наук України

\section{ТИПОЛОГІЯ ВЖИВАНЬ І СЕМАНТИЧНИХ ПЕРЕХОДІВ ЛЕКСЕМ НА ПОЗНАЧЕННЯ ГЛИБИНИ В УКРАЇНСЬКІЙ, ПЕРСЬКІЙ ТА АЗЕРБАЙДЖАНСЬКІЙ МОВАХ}

\begin{abstract}
У статті за допомогою семантичної метамови (найважливішими компонентами якої є спостерігач; вертикальність; поверхня; фасад (перед, лице) і протилежний йому тильний бік (тил, зад) об'єктів; внутрішність; порожнє/повне (категорії опису об'єктів у формі контейнерів); контейнер, або умістилище; межі; тло; частина/ціле, множина, маса/дискретні (раховані) об'єкти, а також люди та частини тіла людини) побудована лексична типологія прототипових (предметних), розширених (непредметних) та метафоричних ужсивань прикметників та відад'єктивних іменників сучасних української, перської та азербайджсанської мов. Сдина методика паралельних описів у зазначених мовах дозволила, по-перше, виявити три типи вживань лексем на позначення глибини: 1) для опису порожнини всередині контейнера, визначаючи відстань від «входу» до «дна»: рів, яр, озеро, шахта, піала, таз, нора, печера, диван та под.; 2) з іменами на позначення речовин: сніг, пісок, мул, болото; 3) для опису об'єктів, які перебувають під землею або під водою: глибокі поклади вугілля, глибоке коріння, глибоке дно, місие та под. По-друге, виявлені вісім регулярних семантичних переходів у досліджуваних мовах: «контейнер»-речовина (глибоке озеро- глибокий сніг); речовина - постійно розтамований під землею/водою об'єкт (глибокий сніг - глибокі поклади вугілля); «контейнер» - процес, інструмент (глибоке озеро - глибокий друк); речовина - «шар» часу, простору (глибокий сніг - глибока розвідка); постійно розтамований під землею/водою об'єкт - прочес, місие (глибокі поклади - глибоке дихання); «контейнер» - явище, його суб'єкт та результат (глибоке озеро - глибока думка); речовина - фізичний стан, час (глибокий сніг - глибокий сон); постійно розташований під землею/водою об'єкт - почуття (әлибокі поклади - глибокий сум). Настільки експлічитний опис (у ньому явно вказано на умови реалізаиії кожної форми) дозволяє створювати високоякісні словники та граматики досліджуваних мов.
\end{abstract}

Ключові слова: лінгвістична типологія, лексична і семантична типологія, полісемія, метафора, метонімія, прикметники розміру, відад'єктивні іменники розміру.

Постановка проблеми. Інтенсивний розвиток в останні десятиліття лінгвістичної типології доводить слушність передбачення I. О. Бодуена де Куртене, яке він зробив ще в казанських лекціях 70-х років XIX століття, про розуміння в майбутньому лінгвістики як науки про міжмовні переклади. Усі лінгвістичні дисципліни - діалектологія, соціолінгвістика, типологія, порівняльно-історичне мовознавство, нейролінгвістика, перекладознавство та інші - фактично займаються однотипними операціями, скерованими на встановлення відношень між мовними системами. По суті, в будь-якому дослідженні явно чи неявно присутні як мінімум дві співвідносні одна з іншою мовні системи [5, с. 13].
Відповісти ж на запитання, коли саме і де саме було проведено перше зіставлення мовних фактів чи то в науковому, чи то в аматорському плані, мабуть, не $\epsilon$ можливим. Упевнено можна сказати лише те, що порівняльне, в широкому сенсі, вивчення мов виникло разом 3 їх описовим вивченням ${ }^{1}$. I якщо спочатку лінгвістична типологія обмежувалася класифікацією мов (простим зведенням усієї різноманітності людських мов до декількох основних типів), то в останній час типологія перетворилася в розділ мовознавства, метою якого є пізнання

\footnotetext{
${ }^{1}$ На важливому місці зіставних досліджень в історії мовознавчих учень дослідники неодноразово наголошували (див. про це, наприклад, в [31, р. 27-33]).
} 
будови людської мови загалом [15, с. 3], оскільки, по суті, типологічні характеристики мови, на пошук і виявлення яких скеровані зіставні дослідження, $€$ комплексом ідіоетнічних типових мовних одиниць і правил їх уживання, що лексикалізують і граматикалізують процес вербалізації думки певною мовою [6, с. 27]. Однак в усіх опрацьованих на сьогодні глобальних комбінованих мовних типах (типологія порядку слів Дж. Грінберга, контенсивна типологія Г. А. Клімова, типологія вершинного/залежного маркування Дж. Ніколс, синтаксична типологія О. Є. Кібрика, а також класична морфологічна типологія) відсутня лексико-семантична складова (див. про це в [31, p. 38-39]), тобто охоплено лише сферу граматики. Всебічне ж дослідження лексичної семантики на предмет виявлення типологічно релевантних ознак обов'язково приведе до встановлення закономірного зв'язку між лексикою та іншою частиною універсальної граматики. Ця обставина й спричинила інтенсивний розвиток в останні роки лексико-семантичної типології, метою якої став пошук, виявлення і пояснення типологічно суттєвих або релевантних ознак у сфері лексичної семантики (див. про це в: [23; 14; 4]), оскільки са́ме такі ознаки (кожної окремої мови) у своїй сукупності становлять частину універсального лінгвістичного набору ознак людської мови. Такого роду опис системи мови, що грунтується зі свого боку на метамові, тобто на «точній системі понять», придатній для опису різних мов, $є$ особливо актуальним для створення підручників і граматик для іноземців (про актуальність створення метамови семантичного опису та про невирішеність проблеми іiї створення (див. [23, p. 180]). Одиниці такої метамови семантичного опису не мають бути ані обов'язковими для всіх культур, ані відображеними в лексиконах усіх мов $^{2}$. Однак вони можуть бути засвоєні представниками будь-яких мов і культур як принципова можливість зрозуміти предмет дійсності в результаті безпосереднього комунікативного досвіду.

Аналіз останніх досліджень. Розмір є традиційним об'єктом сучасної лінгвістичної семантики, а також однією з найпопулярніших тем лексичної типології ${ }^{3}$ Наріжним моментом у дослідженні

\footnotetext{
$\overline{2}$ Пор. щодо цього висновок у [22], що навряд чи існують універсалії для будь-якого списку слів як для мови в цілому, так і для окремих тематичних груп.

${ }^{3}$ I справді, однією з перших праць, повністю присвячених аналізу лексики з семантикою розміру, була дисертація німецького філолога Карла Отто Коха 1906 (!) року (див.: [3, с. 4]). 3 того часу за охопленням досліджених мов ця категорія не поступається студіям з морфологічної типології та типології порядку слів. (детальний розбір дуже цікавої проблематики цього напряму лінгвістичної семантики, який торкається фундаментальних уявлень лінгвістів про будову мови, див. у: [20; 13; 27; 8, с. 262-286; 25]).
}

цієї групи лексики є те, що при кількісному протиставленні виходять не 3 якихось абсолютних ступенів ознаки, а з кількості ознаки більшої чи меншої за певну середню, нормальну, еталонну величину в даному класі речей (дет. про це див. у $[27 ; 8$, с. 262-286]). Якщо порівняти словосполучення маленький слон і велика миша, то зрозуміло, що йдеться не про величину абсолютну, а про величину відносну у порівнянні з середньою, нормальною для кожного класу тварин (найдовший ніс коротший за найкоротші руки). Крім цього, інформація про розміри об'єктів завжди пов'язана 3 конкретною ситуацією. Наприклад, великий дім у ситуації села та міста є різними будинками за абсолютною величиною. Носії мови з власного досвіду знають приблизні співвідношення в кожному класі речей за кількістю ознаки [10, с. 103]. Тому прикметники розміру передбачають у тлумаченнях своїх значень предмет ${ }^{4}$. Однак, для того, щоби ввести такий «об'єктний» компонент у структуру значення прикметника розміру, слід усі об'єкти, які можуть мати величину, звести до обмеженої кількості типів. Аналіз же функціонально-відображувальних (ономасіологічних) зв'язків більш ніж 400 уживань українських та перських прикметників розміру в межах ад'єктивно-субстантивних словосполучень (ці зв'язки визначалися на основі тлумачних словників сучасних української та перської мов) виявив, що об' $є$ м цих зв'язків значно коливається (дет. див. [8, с. 274-276]).

Більшість членів, так би мовити, «ядра» лексичної підсистеми на позначення розміру та похідні від них (українською великий, маленький, низький, глибокий, більший, найбільший, величезний, тонесенький, тіснуватий та інші; перською - bozorg 'великий', riz 'дрібний', derāz 'довгий', amiq, 'глибокий', nāzok 'тонкий', tang 'тісний', bozorgtar 'більший', bozorg-tar-in 'найбільший', riz-tar-in 'найдрібніший', boland-tar 'вищий' та інші) можна віднести до лексем із широкою іменною приналежністю.

До прикметників з вузькою об'єктною приналежністю можна зарахувати такі слова: українською іграшковий, кишеньковий, куций, малорослий, приземкуватий, мініатюрний, маломірний, низькостеблий, мілкий, малометражний та інші.; перською - laqar 'худий', farbe, čak 'товстий', kutuke 'карликовий', miniaturi 'мініатюрний' та інші, зокрема, деякі похідні від них. Ці при-

\footnotetext{
${ }^{4}$ Недарма один 3 найпослідовніших прибічників необхідності синтаксичного компонента в лексичній семантиці Манфред Бірвіш вважав, що створити точну теорію значення можна лише міцно зв'язавши іiі з синтаксисом (див. [1]).
} 
кметники можуть обмежуватися родовою сполучуваністю (українською жирний, тлустий, тілистий (люди, тварини), низькостеблий (рослини), буйний (множини та окремі «безформні» об'єкти, які утворюють однорідні сукупності та явно чи уявно сприймаються мовцем на їх тлі, однак, на відміну від рос. крупний, описує лише натурфакти, тобто те, що може буяти, пор.: буйна верба, буйне волосся, буйні зерна), перською: farbe 'товстий' (люди, тварини)); видовою (українською маломірний, повномірний (взуття), портативний (радіоприлади), перською - shakhis 'дорідний' (про чоловіків), kam-āb 'мілководний' (про водойми), jam'-o-jur 'компактний' (про обладнання, пристосування)); і навіть індивідною (українською вузькоколійний (залізниця), додільний (сорочина або одежина на зразок сорочки), перською - shahlā 'великі й гарні' (про очі), shāhvār 'дорідний' (про перлини) та інші). Крім того, деякі прикметники цієї групи можуть сполучатися 3 іменниками відразу кількох тематичних груп: дорідний (про людей та про все, що людина «родить», пор.: дорідний мужчина, дорідна постать, дорідна пшениия, лани, дорідний врожай), присадкуватий (люди, тварини, будівлі, деякі вироби, наприклад, скриня), пер. то 'zam 'великий' (споруди, відкриті простори), тим самим наближаючись до прикметників широкої іменної приналежності.

Натомість прикметники 3 широким відображувальним потенціалом можуть сполучатися 3 іменниками різних референтних класів: «люди», «тварини», «тіло» та його частини, «рослини» та їхні частини, «будівлі» та їхні частини, «одяг» та його частини, «меблі» та їхні частини, предмети побуту (тобто «артефакти»), природні утворення (тобто «натурфакти») та інші. Як бачимо, сполучувальний потенціал цієї групи ад'єктивних слів практично необмежений. Однак, кожний зі згаданих прикметників цієї групи в обох мовах, зі свого боку, також має сполучувальні обмеження. Так, українські прикметники великий, малий, маленький та їх перські відповідники - bozorg, kuchak й деякі похідні від них у прямих значеннях не сполучаються: з іменниками на позначення сукупності однорідних предметів, у тому числі рідких (вода, чай, чорнило), сипких (пісок, злаки), хімічних сполук (метал, срібло); $з$ іменниками, що мають визначений розмір, наприклад, грошові одиниці, назви мір та подібне; з іменниками, 3 конкретним розміром яких люди практично ніколи не стикаються (серце, нирка), а також деякими іншими. Високий, низький - 3 іменниками на позначення одягу та його частин (за винятком комір), з деякими іменниками на позначення природних утворень, наприклад, ріка, озеро, галявина та подібне. Як бачимо, у межах цієї групи обсяг зв'язків її членів (ад'єктивів з об'єктами-носіями ознаки (субстантивами)) також коливається. Ці особливості семантичної сполучуваності прикметників розміру не дозволяють без спеціального дослідження розкрити іiі мотивацію. Серії іменників, які об'єднані можливістю мати одне й те саме означення, не відповідають ні так званим «природним підкласам», ні підкласам «предметних» i «предикатних» імен, проте, навпаки, становлять змішані стосовно до цих категорій групи. Один і той самий ряд може складатися з назв осіб, предметів (природних і штучних), класифікуючих імен і назв подій.

У свій час Леонард Талмі [32] запропонував відмовитися від геометричного «вимірювання» об'єктів та їх біологічного класифікування. Автор вважає, що підхід, при якому в кожного об'єкта можна виміряти довжину, ширину, товщину та інше, накинутий нам евклідовою геометрією і не пов'язаний $з$ тими уявленнями про простір, які відображає наша мова. Мова ж оперує не геометрією, а топологією об'єктів. Тобто носій мови уявляє собі вертикально витягнуті предмети жорсткої конфігурації, що стоять окремо - «шпилі» (вежа, башта, дерево, труба, комин та подібні); піднесені над поверхнею «опори» (сидіння, крісло, стіл, ліжко та подібні); предмети, що постійно перебувають над поверхнею, основою (гілка, хмари); витягнуті предмети жорсткої конфігурації - «стрижні» (дошка, ивях, нігті, ніс та подібні); шнуркоподібні предмети (волосся, шия та подібні); речовини (сніг, вода, пісок та подібні); місткості постійної форми - «контейнери» (таз, озеро та подібні); об'єкти, що розташовані в глибині (коріння); «пластини» (плита, килим та подібні); «м'які» місткості (черево, гаманещь, папка та подібні); «поверхні» (стіл, дошка, спина та подібні); «безмежні» простори (море, cmen та подібні); «отвори» (щілина, труба, лаз та подібні); «безформні» об’єкти (пляма, квадрат, трикутник, слід та подібні) [13; 11, с. 127].

Однак, для зарахування об'єкта до певного топологічного типу, окрім форми, суттєвим $є$ його оріснтація в просторі. Ідею про вплив орієнтації об'єкта в просторі на «вимірювання» його протяжностей висловили Евалд Ланг і Кай-Уве Карстенсен наприкінці 80-х років (див. [25]). Автори розділяють об'єкти на п’ять груп: фіксованої орієнтації (хмарочос, димар, яма, озеро та подібні); канонічної орієнтації (можуть бути повернутими 
або перекинутими, наприклад, дерево, шафа та подібні); успадкованої орієнтації (пляшки, банки та подібні); імена, що «набувають орієнтації завдяки контексту» (наприклад, словосполучення глибокий капелюх - правильне, лише коли прагматичний контекст дозволяє уявити капелюх перекинутим) (дет. див. [12, с. 2]).

У межах цього підходу сформувалася власна метамова. Серед головних іiі компонентів слід згадати: спостерігача (людина завжди описує дійсність з якогось пункту спостереження); вертикальність (визначає позицію об'єкта за відношенням до поверхні Землі та є орієнтованою на стандартну позицію людини); поверхню (характеризує об'єкти 3 виокремленими, видимими межами); фасад (перед, лице) і протилежний йому тильний бік (тил, зад) об'єктів (пов'язані 3 уявленням про зовнішній вигляд людини (перед=лице) та керунком його руху (людина йде вперед), (таке уявлення переноситься на неживі об'єкти, на кшталт, шаф, будівель та подібного); внутрішність (для людини $\epsilon$ необхідним у кожний момент відчувати себе в певному пункті простору: близько/далеко, тут/там, в/поза та подібне); порожнє/повне (категорії опису об'єктів у формі контейнерів); контейнер або вмістилище (ознака «вмістилища» або «включення» грунтується на фундаментальній властивості сприйняття людиною відношень включення одного об' єкту в інший, або відношення вмісту та вмістилища); межі (уявлення про простір містять й певні видимі (!) межі, оскільки безмежних для нашого сприйняття просторів не буває); тло (воно може сприйматися зором (слід, буква) або ж бути присутнім у свідомості, коли предмет порівнюється з однорідними, частину/ціле, множина, масу/дискретні (раховані) об'єкти (ці поняття описують уживання, на кшталт російською большая картошка - крупный картофель та інше) $)^{5}$. Антропоцентричність виражається в тому, що в опис будь-якого фрагмента семантики, пов'язаної з простором, обов'язково вводяться люди та частини тіла людини ${ }^{6}$.

Наостанок слід зауважити, що в межах лексичної або лексико-семантичної типології сформувалося, так би мовити, дві дисципліни 3 дуже близьким науковим апаратом. Вони мають різні назви, а нерідко в спеціальній літературі не розрізняються. Однією 3 них є лексична або лек-

\footnotetext{
$\overline{5}$ Детальніше про понятійні, або когнітивні, конструкти для опису мовної семантики див., наприклад: [2; 17, с. 347 та наст.; 7].

${ }^{6}$ Так, в усіх мовах світу існують спеціальні лексеми на позначення аналогічних якостей людини: зріст, огрядний, жирний, тлустий, худий та под. (див [26; 29]).
}

сико-семантична типологія, де об'єктом є слова конкретних мов, для яких визначається розподіл семантичного матеріалу. Іншою - семантична типологія, де об' єктом є пари значень, що виявляють концептуальну суміжність. Слова при такому підході лише реалізують семантичний перехід (див. про це в: [33; 35; 4, с. 38, 35]).

Постановка завдання. Метою є проведення дослідження в межах двох названих підходів: спершу на основі семантичної метамови провести паралельний опис лексем на позначення висоти в зазначених мовах та, як результат, побудувати лексичну типологію їх вживань; далі, на основі цих даних, побудувати типологію семантичних переходів лексем на позначення висоти в зазначених мовах. Дослідження $є$ продовженням серії статей про семантичну типологію концепту ВЕЛИЧИНА (попередні див. [9; 24])

Виклад основного матеріалу. Матеріалом дослідження стали понад дві тисячі мінімальних контекстів (словосполучень) прикметників та іменників сучасних української, перської та азербайджанської мов зі значенням глибини, які визначалися за результатами сумарного аналізу тлумачних словників цих мов, матеріалу спеціальних розвідок, різножанрових текстів, а також результатів опитування інформантів-носіїв зазначених мов.

Прототипові (предметні) контексти. Прототиповою ситуацією для цієї групи прикметників $\epsilon$ опис виміру, скерованого вздовж погляду глядача всередину об'єкта. В українській мові прикметником, що описує такий вимір, є глибокий. Йому притаманні три типи вживань:

- для опису порожнини всередині контейнера, визначаючи відстань від «входу» до «дна»: рів, яр, озеро, шахта, піала, таз, нора, печера, диван;

- 3 іменами на позначення речовин: сніг, пісок, мул, болото.

Ці два топологічні типи об'єктів - «контейнери» та «речовини»- мають тісний онтологічний зв'язок, який виявляється в можливості вживання імен на їх позначення в конструкції з прийменником $8(y): \boldsymbol{y}$ глибокій ущелині; $\boldsymbol{y}$ глибокому снігу;

- для опису об'єктів, які перебувають під землею або під водою: глибокі поклади вугілля, глибоке коріння, глибоке дно, місие. Такий «дистантний» тип уживання глибокий має тісний онтологічний зв'язок $з$ двома попередніми. По-перше, у деяких випадках спостерігається конкуренція між дистантною та просторово-кількісною інтерпретаціями, наприклад, у виразі «кроти прорили 
глибокі ходи по иілому саду» є незрозумілим, чи то ходи розташовані на великій відстані від поверхні землі (дистантне тлумачення), чи то ходи були дуже довгими в глибину, тобто є заглибленими в поверхні землі - «контейнерами». Така сама двоякість розуміння виникає для словосполучень печери, тунелі, нори. По-друге, характеристика об'єкта, що є на глибині, аналогічно до порожнини контейнера, повинна бути постійною, тобто дистантно розташований об'єкт не може бути рухомим, пор.: *глибокий якір, глибокі підводні човни, глибокі риби.

Антонімом до глибокий у прототипових контекстах виступає префіксальний прикметник неглибокий: неглибока нора, затока, неглибокий сніг, мул, неглибоке крісло, неглибоке коріння ${ }^{7}$

У перській мові близьким відповідником глибокий є amiq. Йому також приманні три типи вживань:

- для опису порожнини всередині контейнера: boridegihā-ye amiq 'глибокі розрізи', darrehā-ye amiq 'глибокі ущелини', daryā-ye amiq 'глибоке море', khandaq-e amiq 'глибокий окоп'. Синонімом amiq у «вимірювальних» контекстах виступає прикметник gowd: jā-ye pā-ye gowd 'глибокий слід ноги', darre-ye gowd 'глибока ущелина'. відміну від $a m i q$ порожнини можуть бути «повернутими», пор.: chashmhā-ye be gowd neshaste 'глибоко посаджені очі', chashmhā-ye gowd oftāde 'впалі очі', tāqche-ye gowd 'глибока полиця';

- 3 іменами на позначення речовин: barf-e amiq 'глибокий сніг';

- на позначення об'єктів, які перебувають під землею або під водою: faj-e amiq 'глибока дорога, шлях (що проходить глибоко в ущелині)'.

В азербайджанській мові близьким відповідником глибокий $є$ dərin. Йому також приманні три типи вживань:

\footnotetext{
${ }_{7}^{7}$ Прикметник мілкий, етимологічно пов'язаний 3 «мілина», сполучається виключно з іменами на позначення водоймищ, причому лише природних водойм, пор.: мілка річка, мілкий ставок, брід, але не *мілка криниия. Прикметник мілкий у сполученнях з артефактами може вживатися лише в спеціальних фразеологічних контекстах: мілка тарілка. Річ у тім, що об'єкти, описувані прикметником глибокий, зазвичай мають обмеження у власній семантиці щодо незначної протяжності в глибину (пор. дещо неприродні сполучення мілке море, мілка затока), його головним антонімом слід таки визнати неглибокий: неглибока печера, неглибока шахта, неглибоке озеро, у неглибокому Аральському морі не можуть ходити великотоннажні кораблі.

${ }^{8}$ Ця лексема має ще два іменникових значення - 'яма' та 'увігнуте заглиблення', - які досить прозоро визначають сферу його вживання, пор.: boshqāb-e gowd 'глибока тарілка'.

${ }^{9}$ Ще одним синонімом amiq є прикметник žarf, який має яскраво виражений книжний відтінок (пор. укр. глибоченний, глибочезний).
}

- для опису порожнини всередині контейнера: dərin yarlq 'глибокий розріз', dərin göl 'глибоке озеро'. Рідко (лише з натур фактами, де контекст допускає такі вживання) антонімом до dərin виступає прикметник dayaz: dayaz yuva 'неглибока нора'; dayaz gölməçə 'мілка калюжа';

- 3 іменами на позначення речовин: darin qar 'глибокий сніг';

- на позначення об'єктів, які знаходяться під землею або під водою: darin kömür yataqlarl 'глибокі поклади вугілля'; dərin köklar 'глибоке коріння'.

Розширені контексти. Серед уживань аналізованих прикметників допустимими $€$ їх сполучення з іменами на позначення дещо відмінних від предметних явищ. Це, по-перше, відпредикатні імена, які позначають просторову орієнтацію події або учасників події. Стисло кажучи, ці ситуації здебільшого описуються відповідними прислівниками (пор. глибоко бурити), але іноді цю роль беруть на себе прикметники. По-друге, це імена на позначення об'єктів, які не входять до переліку ïx прототипових топологічних типів, однак описуються прикметниками розміру завдяки метонімічному переносу (див. нижче) ${ }^{10}$. До того ж сполучення прикметників з іменами на позначення непредметних ситуацій відбувається за аналогією 3 типами їх уживань у предметних контекстах.

У розширених непредметних та метонімічних контекстах з глибокий представлені усі три типи предметних інтерпретацій:

- «контейнери»: техніка глибокого буріння, глибоке буріння (процес, у результаті якого виникає скважина великої глибини), глибокий друк (термін на позначення способу друку, коли друковані елементи, що заливають фарбою, є заглибленими);

- «шари»: глибока старовина, давнина («шари» часу, на «дні» яких знаходиться певна подія), глибокий ліс, глибокий тил (на глибині від умовної лінії відліку - фронту; тут концептуалізовано простір «горизонтального шару»);

- «дистанція»: глибоке дихання, зітхання (процес, коли при вдиханні повітря задіяно «нижні» органи), кашель, голос, подих, вдих (місце, де відбувається утворення дихання, звуку; пор. неможливе * глибокий видих).

У перській мові у розширених контекстах 3 amiq представлено усі три типи прототипових предметних інтерпретацій:

\footnotetext{
${ }^{10}$ Про проблему розрізнення метафори та метонімії, а також про протиставлення понять «подібність» та «суміжність» (див. [21, p. $17 ; 19$, р. 2-21]). Про зміну актантів при метонімізації та, ширше, як процес метонімізації відбивається на граматиці (див. [28]). Про суміжність як найважливіше явище семантичної деривації (див. [30, p. 423]).
} 
- «контейнери»: haffāri-ye amiq 'глибоке буріння';

- «шари»: ekteshāf-e amiq 'глибока розвідка (дослідження)';

- «дистанція»: āh-e amiq 'глибоке зітхання', nafas ' дихання', nafas-e amiq kashidan 'глибоко зітхати'.

В азербайджанській мові у розширених контекстах 3 dərin представлено усі три типи предметних інтерпретацій:

- «контейнери»: dərin çар 'глибокий друк';

- «шари»: dərin geoloji kəşfiyyat 'глибока геологорозвідка';

- «дистанція»: dərin nəfəs 'глибоке дихання', öskürək 'кашель'.

Метафоричні контексти. Метафоричними ми називаємо такі контексти, в яких «порушено» топологічні обмеження на тип імені у сполучуваності прикметника. Однак, порушення законів сполучуваності не $є$ випадковими та підпорядковуються певним закономірностям. Так, усі такі «порушення» 3 високий вкладаються в схему його прототипових предметних уживань:

- «контейнери»: глибокі зміни, глибока музика, думка, проблема, натура, людина, особистість, глибокий твір (зміст цих понять уявляється таким, що знаходиться в «місткості», «посудині» й щоби зрозуміти глибину цієї ємкості, їі слід «виміряти», вичерпавши зміст); глибокий nоет, філософ (згідно зі стандартним метонімічним перенесенням); глибоке дослідження, аналіз, глибоке знання предмету (семантична структура таких сполучень $€$ аналогічною до метонімічних (на кшталт, глибоке буріння), оскільки ці імена також є двомісними й глибокий стосується другого актанта, тобто хтось, досліджуючи, аналізуючи, вивчаючи, «проникає» в зміст питання, ситуації, та в результаті опиняється в глибині питання, ситуації); глибокий розум, думка (тут розум та думка інтерпретуються за аналогією 3 глибокий бур як інструмент для глибокого проникнення в зміст ситуації, тобто має місце метонімічне перенесення сфери дії глибокий з валентністю змісту на інструмент); глибокі протиріччя, непорозуміння, недовіра (тут імена асоціюються 3 межами, перешкодами, а прототиповими природними перешкодами є яма, урвище, прірва);

- «речовини»: глибокий сон, смуток, сум, тиша (фізичні стани людини чи середовища уподібнюються щільним рідинам, в які ніби занурюється людина, пор.: він занурився в сон; усе потонуло вмовчанні); глибока осінь, зима, ніч, стаpicmb, давнина (метонімічні перенесення - часові періоди уподібнюються до «застиглих шарів», на відміну від «мінливих», пов'язаних із ростом і рухом, пор.: *глибокий день, весна, молодість, сучасність);

- об'єкти, що перебувають на глибині: глибокий відчай, інтерес, презирство, зачікавленість, нудьга, (почуття людини ніби знаходяться всередині людини на великій глибині - головна річ полягає в тому, щоби вони не мали зовнішніх проявів, тобто не переходили в поведінку, пор.: * бока радість, скромність) ${ }^{11}$.

У перській мові спостерігаємо аналогічну картину:

- «контейнери»: ādam-e amiq 'глибока людина', pishraft-e amiq 'глибокий (не мінливий) поступ', fekr-e amiq 'глибока (виплекана) думка', tariq-e amiq 'глибокий (змістовний, такий спосіб, що принесе багато користі) шлях', naqd-e amiq 'глибокий аналіз', motāle'at-e amiq 'глибоке вивчення';

- «речовини»: khāb-e amiq 'глибокий сон', sokut-e amiq 'глибока тиша';

- об'єкти, що перебувають на глибині: tars-e amiq 'глибокий (постійний, такий, що не минає) страх', mohbat-e amiq 'глибоке (давнє) кохання', dusti-ye amiq 'глибока (щира) дружба' 12 .

В азербайджанській мові категоріальний зсув семантики прикметника dərin діє також за аналогією 3 прототиповими предметними контекстами:

- «контейнери»: darin fikir 'глибока думка';

- «речовини»: darin уихи 'глибокий сон';

- об’єкти, що перебувають на глибині: dərin $k \partial d \partial r$ 'глибока печаль'.

Відад'сктивні імена. Глибина вживається в усіх типах контекстів:

- у прототипових предметних контекстах: глибина криниці, озера, глибиною два метри (тип контейнери); на великій глибині, на глибині двох метрів, океанські глибини (дистантний тип). Таке вживання $\epsilon$ можливим й для «повернутого» (горизонтального) простору, наприклад: у глибині кімнати, сиени, острова, країни, біль у глибині грудей;

- у розширених непредметних контекстах глибина описує внутрішній простір процесів, що

\footnotetext{
${ }^{11}$ Існують перехідні - між почуттями та поведінкою випадки, наприклад, кохання, тому сполучення глибоке кохання (?) хоча і є можливим, однак у дуже вибагливих контекстах.

12 У художньому мовленні в метафоричних контекстах нерідко виступає žarf. Цікавим є те, що метафоричність його значення аналогічна предметним вживанням: «контейнери»: t'asiri žarf 'глибокі наслідки', farqi žarf 'глибочезна різниця', sokhan-e žarf 'глибокі (важливі та важкі) слова', negāh-e žarf ‘прискіпливий погляд, глибокий розгляд’; «дистантний» тип: dusti-ye žarf 'глибока (давня, щира) дружба', anduh-e žarf 'глибоченне горе'.
} 
асоціюються 3 контейнерами (та отворами): глибина буріння, друку. В окремих випадках глибина може описувати дистантні характеристики: глибина голосу, дихання, стогону;

- у метафоричних контекстах сполучення 3 глибина також розподіляються серед цих двох типів уживань: глибина проблеми (тип «контейнери»), глибина протиріч, суму (дистантний тип).

У перській мові іменник omq також вживається в усіх типах контекстів:

- у прототипових предметних контекстах $o m q$, по-перше, позначає величину, що вимірює відстань «до дна» контейнерів та отворів: omq-e howz 'глибина басейну', omq-e zamin 'глибина землі', omq-e qār 'глибина печери', omq-e chāh 'глибина ями', по-друге, omq позначає простір, який знаходиться далеко від зовнішньої поверхні, близько до «дна», тобто за дистантним типом вживання: be omq-e daryā 'у глибину моря', az omq-e darre sedāyi be kush mirasid 'з глибини печери, ущелини доносився голос'. Таке вживання $o m q$ $\epsilon$ можливим й для «перевернутого» простору, пор.: omq-e dasht 'глибина степу' (прагматично вишуканий контекст);

- у розширених непредметних контекстах $o m q$ описує внутрішній простір процесів, що асоціюються 3 контейнерами (та отворами): čāp-e omq 'глибина друку';

- у метафоричних контекстах сполучення з omq розподіляються серед цих двох типів уживань: omq-e fäje'e 'глибина горя, трагедіï', omq-e dosti 'глибина дружби' (тип «контейнери»), dar omq-e zehn 'у глибині свідомості, мозку', dar omq-e anduh 'у глибині горя, смутку' (дистантний тип), vos'at va omq-e zendegi ‘безмежність та глибина життя'.

В азербайджанській мові відад'єктивні іменники мають дуже обмежене використання (замість них використовуються прикметники), але в рідкісних уживаннях dərinlik аналогічно українському - глибина і перському - omq уживається в усіх контекстах: böyük dərinlik 'велика глибина'; düşüncə darinliyi 'глибина думки'.

Усе сказане можна схематично підсумувати в такому вигляді.
Контексти

Прототипові (предметні)

Розширені (непредметні, метонімічні)

Метафоричні
«Контейнери»

глибоке озеро / daryāče-ye amiq / dorin göl

глибокий друк / čāp-e amiq / dorin çap

глибока думка / fekr-e amiq / dorin fikir
«Речовини»

Під землею/водою глибокий сніг / barf-e amiq / глибокі поклади вугілля / zahāyer-e dorin qar amiq / dorin kömür yataqlarl глибока розвідка/ ekteshāf-е глибоке дихання / nafas-e amiq / amiq / darin geoloji kaşfyyyat dorin nafas

глибокий сон / khāb-e amiq / dorin yuxu глибокий сум / qam-u-anduh-e amiq / dorin kadar
На основі представленої лексико-семантичної типології можна побудувати типологію семантичних переходів лексем на позначення висоти в досліджуваних мовах. Саме́ поняття семантичного переходу є способом відображення того факту, що певні два смисли невипадково виражаються в певній мові тим самим словом - чи то синхронно, у формі двох значень полісемічного слова, чи то діахронічно, у формі етапів семантичної еволюції [4, с. 36].

\section{Семантичні}

Перська

Азербайджанська

переходи

\section{ПРОТОТИПОВІ (ПРЕДМЕТНІ) КОНТЕКСТИ}

«контейнер» речовина

речовина

- постійно розташований під землею/ водою об'єкт daryāěe-ye amiq 'глибоке озеро' $\rightarrow$ barf-e amiq 'глибокий сніг'

barf-e amiq 'глибокий сніг' $\rightarrow$ zahāyer-e amiq 'глибокі поклади (вугілля)' глибоке озеро $\rightarrow$ глибокий сніг глибина озера $\rightarrow$ глибина снігу

глибокий сніг $\rightarrow$ глибокі поклади вугілля глибина снігу $\rightarrow$ глибина покладів darin göl 'глибоке озеро' $\rightarrow$ darin qar 'глибокий сніг'

darin qar 'глибокий сніг' $\rightarrow$ dərin kömür yataqları 'глибокі поклади вугілля'

\section{РОЗШИРЕНІ (НЕПРЕДМЕТНІ, МЕТОНІМІЧНІ) КОНТЕКСТИ}

«контейнер»

- процес, інструмент daryā̌ce-ye amiq 'глибоке озеро’ $\rightarrow$ čāp-e amiq 'глибокий друк' глибоке озеро $\rightarrow$ глибокий друк глибина озера $\rightarrow$ глибина друку darin göl 'глибоке озеро’ $\rightarrow$ dərin çap 'глибокий друк’ 


\begin{tabular}{|c|c|c|c|}
\hline $\begin{array}{l}\text { речовина - } \\
\text { «шар» часу, } \\
\text { простору }\end{array}$ & $\begin{array}{l}\text { barf-e amiq 'глибокий сніг' } \\
\rightarrow \text { ekteshäf-e amiq 'глибока } \\
\text { розвідка' }\end{array}$ & $\begin{array}{l}\text { глибокий сніг } \rightarrow \text { глибока } \\
\text { розвідка } \\
\text { глибина снігу } \rightarrow \\
\text { глибина розвідки }\end{array}$ & $\begin{array}{l}\text { darin qar 'глибокий сніг’ } \rightarrow \\
\text { dorin geoloji kəşfiyyat ‘глибока } \\
\text { розвідка' }\end{array}$ \\
\hline $\begin{array}{l}\text { постійно } \\
\text { розташований } \\
\text { під землею/ } \\
\text { водою об'єкт - } \\
\text { процес, місце }\end{array}$ & $\begin{array}{l}\text { zahāyer-e amiq 'глибокі } \\
\text { поклади (вугілля)' } \rightarrow \\
\text { nafas-e amiq 'глибоке } \\
\text { дихання' }\end{array}$ & $\begin{array}{l}\text { глибокі поклади вугілля } \rightarrow \\
\text { глибоке дихання } \\
\text { глибина покладів } \rightarrow \\
\text { глибина дихання }\end{array}$ & $\begin{array}{l}\text { dərin kömür yataqlart 'глибокі } \\
\text { поклади вугілля’ } \rightarrow \text { dərin } \\
\text { nəfəs 'глибоке дихання' }\end{array}$ \\
\hline МЕТАФОРИЧ & I КОНТЕКСТИ & & \\
\hline $\begin{array}{l}\text { «контейнер» } \\
\text { - явище, його } \\
\text { суб'єкт та } \\
\text { результат }\end{array}$ & $\begin{array}{l}\text { daryāče-ye amiq 'глибоке } \\
\text { озеро' } \rightarrow \text { fekr-e amiq } \\
\text { 'глибока думка' }\end{array}$ & $\begin{array}{l}\text { глибоке озеро } \rightarrow \text { глибока думка } \\
\text { глибина озера } \rightarrow \text { глибина думки }\end{array}$ & $\begin{array}{l}\text { darin göl ‘глибоке озеро’ } \rightarrow \\
\text { darin fikir ‘глибока думка' }\end{array}$ \\
\hline $\begin{array}{l}\text { речовина - } \\
\text { фізичний стан, } \\
\text { час }\end{array}$ & $\begin{array}{l}\text { barf-e amiq ‘глибокий сніг’ } \\
\rightarrow \boldsymbol{k h a \overline { b }} \text {-e amiq 'глибокий } \\
\text { сон’ }\end{array}$ & $\begin{array}{l}\text { глибокий сніг } \rightarrow \text { глибокий сон } \\
\text { глибина снігу } \rightarrow \text { глибина сну }\end{array}$ & $\begin{array}{l}\text { darin qar 'глибокий сніг’ } \rightarrow \\
\text { darin yuxu 'глибокий сон' }\end{array}$ \\
\hline $\begin{array}{l}\text { постійно } \\
\text { розташований } \\
\text { під землею/ } \\
\text { водою об'єкт - } \\
\text { почуття }\end{array}$ & $\begin{array}{l}\text { zahāyer-e amiq 'глибокі } \\
\text { поклади (вугілля)' } \rightarrow \text { qam- } \\
\text { u-anduh-e amiq 'глибокий } \\
\text { сум’ }\end{array}$ & $\begin{array}{l}\text { глибокі поклади вугілля } \rightarrow \\
\text { глибокий сум } \\
\text { глибина покладів } \rightarrow \text { глибина } \\
\text { суму }\end{array}$ & $\begin{array}{l}\text { darin kömür yataqlart ‘глибокі } \\
\text { поклади вугілля’ } \rightarrow \text { dərin } \\
\text { kədər 'глибокий сум’ }\end{array}$ \\
\hline
\end{tabular}

Неможливо не зауважити дивовижний паралелізм процесів полісемії в неблизькоспоріднених мовах. Наведений матеріал доводить слушність висновків дослідників про те, що асоціації, що лежать в основі метафор і метонімій, що паралельно виникли в різних мовах, швидше за все глибоко вкорінені в людському досвіді та значною мірою не залежать від культури чи середовища [4, с. 37].

Висновки і пропозиції. Практика викладання іноземних мов показує, що численні труднощі, що виникають в учнів, пов' язані якраз із тим, що наявні словники та навчальні посібники не повною мірою передають семантичні компоненти одиниць мови, яку вивчають. Головною вадою більшості словників і навчальних посібників є відсутність системи контрастивної та типологічної семантики мовних одиниць [16, с. 8]. Ще Р. Якобсон наголошував на тому, що важко переоцінити те, наскільки великою є потреба, а також якою є теоретична та практична вартість двомовних словників, які надавали б ретельно виконані порівняльні дефініції усіх відповідних одиниць стосовно їхніх значень і сфери вживання. Так само необхідними $\epsilon$ двомовні граматики, в яких унаочнювалося б те, що об'єднує і що розрізняє певну пару мов у виборі та розмежуванні мовних категорій [18, с. 363]. Створення відповідно високоякісних словників, які $є$ підгрунтям для глибокого розуміння семантики слів, можливо лише на основі міцної теоpiï та глибоких системних досліджень лексичної та граматичної семантики. А в сучасній «пояснювальній» лінгвістиці давно та яскраво описано, що системність у семантиці забезпечується не дією придуманих людьми логічних правил, а антропоцентричною оріснтованістю мовного механізму як цілковито самостійної, що спирається на власні закони та правила, системи [13, с. 80].

Саме 3 цієї причини, при міжмовному описі досліджуваної групи лексики ми відмовилися від традиційних структурних методик відтворення семантики лексики. Наш опис відповідає трьом важливим критеріям подання матеріалу в сучасних словниках. По-перше, на відміну від традиційної лексикографіï, яка орієнтувалася на опис окремого слова як самостійного об'єкта дослідження, на перший план виходить представлення класів слів, об'єднаних за однією або кількома ознаками. По-друге, поруч із поданням змісту смислових та лексичних одиниць мови представлено семантичні зв'язки між ними. По-третє, опис відповідає принципу антропоцентризму, тобто є максимально орієнтованим на зручність сприйняття цього опису, а саме, врешті-решт, на наївне сприйняття. Інакше кажучи, опис відповідає найважливішій властивості - експліцитності, тобто коли в ньому явно вказано на умови реалізації даної форми, коли за певним значенням ми можемо побудувати відповідну йому форму та певній формі приписати іiі значення (саме це й робить носій мови, коли говорить чи слухає). 


\section{Список літератури:}

1. Бирвиш М. Семантика. Новое в зарубежной лингвистике. Вып. Х. Лингвистическая семантика / сост., общ. ред. и вступ. ст. В. А. Звегинцева. Москва : Прогресс, 1981. С. 177-199.

2. Гжегорчикова Р. Понятийная оппозиция вверх-низ (пол. 'wierzch'-'spód') и языковая модель пространства. Логический анализ языка. Языки пространств / отв. ред.: Н. Д. Арутюнова, И. Б. Левонтина. Москва : Языки русской культуры, 2000. 448с. С. 78-83.

3. Денисова О. К. К вопросу об истории развития группы прилагательных, обозначающих понятие размера «высокий-низкий» в древнеанглийский период : Уч. зап. Иркутского гос. пед. ин-та иностр. яз. 1960. Вып. 4. С. 2-45.

4. Зализняк Анна А. Семантический переход как объект типологии. Вопросы языкознания. 2013. № 2. C. 32-51.

5. Иванов Вяч. Вс. Лингвистика как теория отношений между языковыми системами и ее современные практические приложения. Лингвистические исследования по машинному переводу. Москва : Изд-во ВИНИТИ, 1961. Вып. 2. С. 5-28.

6. Кибрик А. Е. Как или Почему? (Об основном вопросе типологии). Типология и грамматика. Москва : Наука. Главная редакция восточной литературы, 1990. С. 21-28.

7. Кубрякова Е. С. Семантика в когнитивной лигвистике (о концептах КОНТЕЙНЕРА и формах его объективации в языке). Известия РАН. Сер. ЛиЯ. 1999. Т.58. № 5-6. С. 3-12.

8. Кшановський О. Ч. Перська мова у функціонально-типологічному висвітленні. Київ : Видавничий Дім Дмитра Бураго, 2011. 424 с.

9. Кшановський О. Ч. ВЕЛИЧИНА в українській, перській та азербайджанській мовах (міжмовна типологія прямих та переносних уживань у різних контекстах). Поміж мов $і$ культур: методологічний еклектизм і міждисииплінарність сучасного мовознавства: колективна монографія / гол. ред. К. І. Мізін. Переяслав-Хмельницький; Кременчук : Вид. ПП Щербатих О. В., 2017. 382 с. С. 333-348.

10. Никитин М. В. Основы лингвистической теории значении: учеб. пособие. Москва : Высшая школа, 1988. $168 \mathrm{c}$.

11. Рахилина Е. В. Атрибутивные конструкции с русскими прилагательными размера: частный случай. Nazwy barw i wymiarow / Colour and measure terms (Stockholm Slavic Papers 6). Stockholm : Akademitryck, 1997. P. 121-128.

12. Рахилина Е. В. Высокий VS. глубокий в русском языке (1999, машинопис).

13. Рахилина Е. В. Семантика размера. Семиотика и информатика. Москва : «Языки русской культуры», «Русские словари», 1995. Вып. 34. С. 58-81.

14. Рахилина Е. В., Плунгян В. А. О лексико-семантической типологии. Глаголы движения в воде: лексическая типология / ред. Т. А. Майсак, Е. В. Рахилина. Москва : Индрик, 2007. С. 9-26.

15. Солнцев В. М. Лингвистическая типология и общая теория типологии. Лингвистическая типология / отв. ред. В. М. Солнцев, И. Ф. Вардуль. Москва : Наука, 1985. С. 3-5.

16. Стернин И. А., Харитонова Б. И. Типы русско-немецких лексических соответствий. Контрастивные исследования русского и немеикого языков. Воронеж: ВГУ, 1986. С. 8-17.

17. Ченки А. Семантика в когнитивной лингвистике. Современная американская лингвистика: Фундаментальные направления / под ред. А. А. Кибрика, И. М. Кобозевой и И. А. Секериной. Изд. 2-е, испр. и доп. Москва : Эдиториал УРСС, 2002. С. 340-369.

18. Якобсон Р. О лигвистических аспектах перевода. Якобсон Р. Избранные работы / Пер. с англ., нем., фр. Москва : Прогресс, 1985. С. 361-368.

19. Barnden John A. Metaphor and metonymy: Making their connections more slippery. Cognitive Linguistics. 2010. 21-1. P. 1-34.

20. Bierwisch M., Lang E. (eds.). Dimentional adjectives: grammaticals structure and conceptual interpretation. Berlin, Heidelberg, New York : Springer-Verlag. 1989. 523 p.

21. Evans Vyvyan, Bergen Benjamin K., Zinken Jörg. The cognitive linguistics enterprise: an overview. Evans Vyvyan, Bergen Benjamin K., Zinken Jörg (eds.). The Cognitive Linguistic Reader. 2007. P. 1-36.

22. Fintel Kai von, Matthewson Lisa. Universals in semantics. The Linguistic Review. 2008. 25. P. 139-201.

23. Koptjevskaja-Tamm Maria, Vanhove Martine, Koch Peter. Typological approaches to lexical semantics. Linguistic Typology. 2007. 11. P. 159-185.

24. Kshanovsky O. Ch. The concept of DIMENSION in Ukrainian, Persian and Azerbaijani languages. Petluchenko N.V. (ed.). Concepts and Contrasts. Odesa : Publishing House «Helvetyka». 2017. 632 p. P. 112-121.

25. Lang E., Carstensen K.U., Simmons G. Modelling Spatial Knowledge on a Linguistic Basis. Theory-Prototype-Integration. Berlin, Heidelberg, New York : Springer-Verlag. 1991. 138 p.

26. Linde-Usiekniewcz J. Hipotezy na temat znaczen polskich przymiotnikow wymiaru. Wersija wstepna. Colour and measure terms (Stockholm Slavic Papers 6). Stockholm : Akademitryck. 1997. P. 105-113. 
27. Linde-Usiekniewicz J. Określenia wymiarów w języku polskim. Warszawa: UW. 2000. 267 s.

28. Mendoza Ibanes Francisco Jose Ruiz de, Hernandez Lorena Perez. Metonymy and the grammar: motivation, constraints and interaction. Language and Communication. 2001. 21. P. 321-357.

29. Rachilina J. Określanie wymiarów części ciała w języku rosyjskim. Grzegorczykowa R., Zaron Z. (eds.). Semantyczna struktura stownictwa i wypowiedzi. Warzshawa : Wyd. UW. 1997. P. 91-95.

30. Rainer Franz (2005). Semantic change in word formation. Linguistics. 2005. 43-2. P. 415-441.

31. Ramat Paolo. Typological Comparison: Towards a Historical Perspective. Masayoshi Shibatani and Theodora Bynon (eds.). Approches to Language Typology. Oxford University Press. 1995. 381 p. P. 27-48.

32. Talmy Leonard. How language structures space. Pick H., Acredolo L. (eds.). Spatial orientation: theory, research, and application. New York : Plenum. 1983. P. 225-282.

33. Zalizniak Anna A. A catalogue of semantic shifts: Towards a typology of semantic derivation. Vanhove M. (ed.). From polysemy to semantic change. Towards a typology of lexical semantic associations. Amsterdam, 2008. P. 217-232.

34. Zalizniak, Anna A. The Catalogue of Semantic Shifts: 20 Years Later. Russian Journal of Linguistics. 2018. Vol. 22, № 4. P. 770-787.

35. Zalizniak Anna A., Bulakh M., Ganenkov D., Grunov I., Maisak T., Russo M. The catalogue of semantic shifts as a database for lexical semantic typology. Koptjevskaja-Tamm M., Vanhove M. (eds.). New directions in lexical typology. Linguistics, a special issue. 2012. V. 50. № 3. P. 633-670.

\section{Kshanovsky O. O. USAGE AND SEMANTIC SHIFTS TYPOLOGY OF THE DIMENSIONAL WORDS IN UKRAINIAN, PERSIAN AND AZERBAIJANI}

In the article the lexical typology of prototype (objective), extended (non-objective) and metaphorical usages of adjectives and adjective nouns in the modern Ukrainian, Persian and Azerbaijani languages is constructed using the semantic metalanguage. Its most important components are: the observer; verticality; surface; frontage (front, face) and the opposite back (rear) of objects; inside; empty / complete (categories for the description of objects in the form of containers); container; borders; background; part / whole, set, mass / discrete (calculated) objects, as well as people and parts of the human body. The same (identical) method of parallel descriptions in these languages allowed, first, to identify three types of usages of lexemes with the meaning of depth: 1) to describe the cavity inside the container, determining the distance from the "entrance» to the «bottom»: ditch (moat), ravine, lake, mine, bowl, basin, hole, cave, sofa, etc.; 2) with nouns to denote substances: snow, sand, silt, swamp; 3) to describe the objects that are under the ground or under water: deep deposits of coal, deep roots, deep bottom, place, etc. Second, eight regular semantic shifts in the studied languages were identified: "container》 - a substance (deep lake - deep snow); substance - object permanent located under the ground/water (deep snow - deep coal deposits); «container» - process, tool (deep lake gravure printing); substance - «layer» of time, space (deep snow - deep exploration); object permanent located under the ground/water - process, place (deep coal deposits - deep breathing); «container» - phenomenon, its subject and the result (deep lake - deep thought); substance - physical condition, time (deep snow - deep sleep); object permanent located under the ground/water - feeling (deep coal deposits - deep sadness). Such an explicit description (it clearly indicates the conditions for the implementation of each form) allows us to create high-quality dictionaries and grammars of the studied languages.

Key words: linguistic typology, lexical and semantic typology, polysemy, metaphor, metonymy, dimensional adjectives, dimensional adjective nouns. 